\title{
American Mirror: The Occupation of the 'New World' and the Rise of Architecture as We Know It
}

Fernando Luiz Lara

\begin{abstract}
This paper argues that the rise of architecture as a unique discipline and the conquest of the American continent are not just chronological coincidences but interdependent variables of the same process of modernization. Traditional scholarship in architecture has not entertained those parallel developments at all. The field of architectural history and theory still treats the spatial occupation of the Americas as a consequence of the Renaissance and European modernization, despite a few decades of scholarly literature in related disciplines questioning such assumptions. (Fanon 1961; Said 1978; Dussel 1980; Bhabha 1987; Escobar 1994). Such scholarship demonstrates that the encounter of 1492 and the territorial occupation that followed played a central role in the development of Western culture in general, allowing the extrapolation of the same logic to the architectural discipline in particular.
\end{abstract}

Keywords: Americas, decolonial theory, history of the built environment in the Americas, modern world

In his classic survey book A History of Architecture, Settings and Rituals published in 1985, Spiro Kostof stated that "the rediscovery of the classical past was one of the two great adventures that informed the Renaissance. The other was the exploration and the conquest of America." 1

This statement alone is more than all previous authors ever said about the relationship between the European occupation of the Americas and the Renaissance and, consequently, in the rise of architecture as an autonomous practice. The large majority of our scholarship until very 
recently completely ignored the Atlantic encounter or minimized its role in European developments (Fig. 1). ${ }^{2}$

For instance, Nikolaus Pevsner discussed the protagonism of every Medici and every pope as clients and patrons of the Renaissance but failed to mention who hired Donato Bramante in 1502 to build the Tempietto. ${ }^{3}$ The Tempietto, in the words of Pevsner, was the first monument of what he labeled the "high" in opposition to the "early" Renaissance. The Early Renaissance being the medieval theocratic concepts of Filippo Brunelleschi and Leon Battista Alberti, the High Renaissance being the more abstract anthropocentric concepts of Michelangelo and René Descartes. Pevsner continued his analysis by affirming that the High Renaissance displays a self-consciousness that was a new experience to the West without ever elaborating where such self-awareness might be coming from. ${ }^{4}$ In the footnotes of architectural history, one will find that the Tempietto was commissioned by Isabel de Castilla to celebrate the conquest of Iberia and the "Indies." The church and convent of San Pietro worked as an embassy of the Spanish crown in Rome. Hernando de Colón lived there for two years while arguing for the Spanish claim over the Malacca Islands (presently Malaysia and Singapore) against the Portuguese. ${ }^{5}$

More recently, Liane Lefaivre and Alexander Tzonis located the start of modern architecture around the year 1500 with "the rise of a culture of luxury [that] was possible because of improvements in productivity, stimulating the expansion of commerce and the need to advance industry to produce those goods." " 6 They do not mention that such increase in productivity and commerce was fueled by the colonial appropriation of resources from the Crusades, as well as from the central valley of Mexico and the Peruvian Andes, supporting the exponential growth of global commerce of which Europe had a monopoly in the Atlantic and most of the Pacific Ocean at the time. ${ }^{7}$ Lefaivre and Tzonis continue their argument that "the adoption of efficiency as a design norm and the development of new knowledge to achieve it did not occur first in the construction of spacious, glittering and crafty buildings but in military architecture, specifically in the design of fortifications." ${ }^{8}$ Again they do not mention that the majority of those fortifications were built in La Habana, Veracruz, Cartagena, Salvador de Bahia, and Montevideo, despite numerous mentions of those built in Italy and France.

In this paper, I argue that the rise of architecture as a unique discipline and the conquest of the American continent are not just chronological coincidences but interdependent variables of the same process of modernization. Traditional scholarship in architecture has not entertained those parallel developments at all. The field of architectural history and theory still treats the spatial occupation of the Americas as a consequence of the Renaissance and European modernization, despite a few decades of scholarly literature in related disciplines questioning such assumptions. ${ }^{9}$ As difficult as it is to "prove" anything in architectural scholarship, I am 
confident that asking such questions will lead to a better understanding of the impact of the Americas in the rise of architecture as a discipline. For, in the words of James Blaut, "it is when we come to the larger issues of causation and matters of explaining profound revolutions in history, that Eurocentrism exerts its important influence." 10

For instance, we need to ask why Alberto Perez-Gomez, who in Architecture and the Crisis of Modern Science (1983) ${ }^{11}$ gave us one of the most complete analyses of the rise of architecture as a discipline from the fifteenth to the eighteenth century, completely ignored the impact that his native land of Mexico might have had in this development. ${ }^{12}$ All those authors were deeply embedded in the traditional European narrative about the Americas being a secondary outcome of European modernity, and therefore not worthy of much attention. The fact that Kostof did not ignore it was in itself an advancement, but one paragraph down (on the same page 433) he held his Eurocentrism steady by elaborating that "these newfound cultures should have proved that the worth of Western achievement was only relative, and forced it into fresh channels. They did not. The riches of the conquered New World added nothing to the enrichment of the Christian west except in the material sense." 13

Much to the contrary, the recent works of Arturo Escobar, Walter Mignolo, Enrique Dussel, David A. Brading, and Ricardo Padron demonstrate that the encounter of 1492 and the territorial occupation that followed played a central role in the development of Western culture in general, allowing me to extrapolate that to the architectural discipline in particular. ${ }^{14}$

A quick summary of the rise of architecture as a discipline in the late fifteenth and early sixteenth century takes us from Filippo Brunelleschi's Ospedale degli Innocenti (1419-1445) to Leon Battista Alberti's

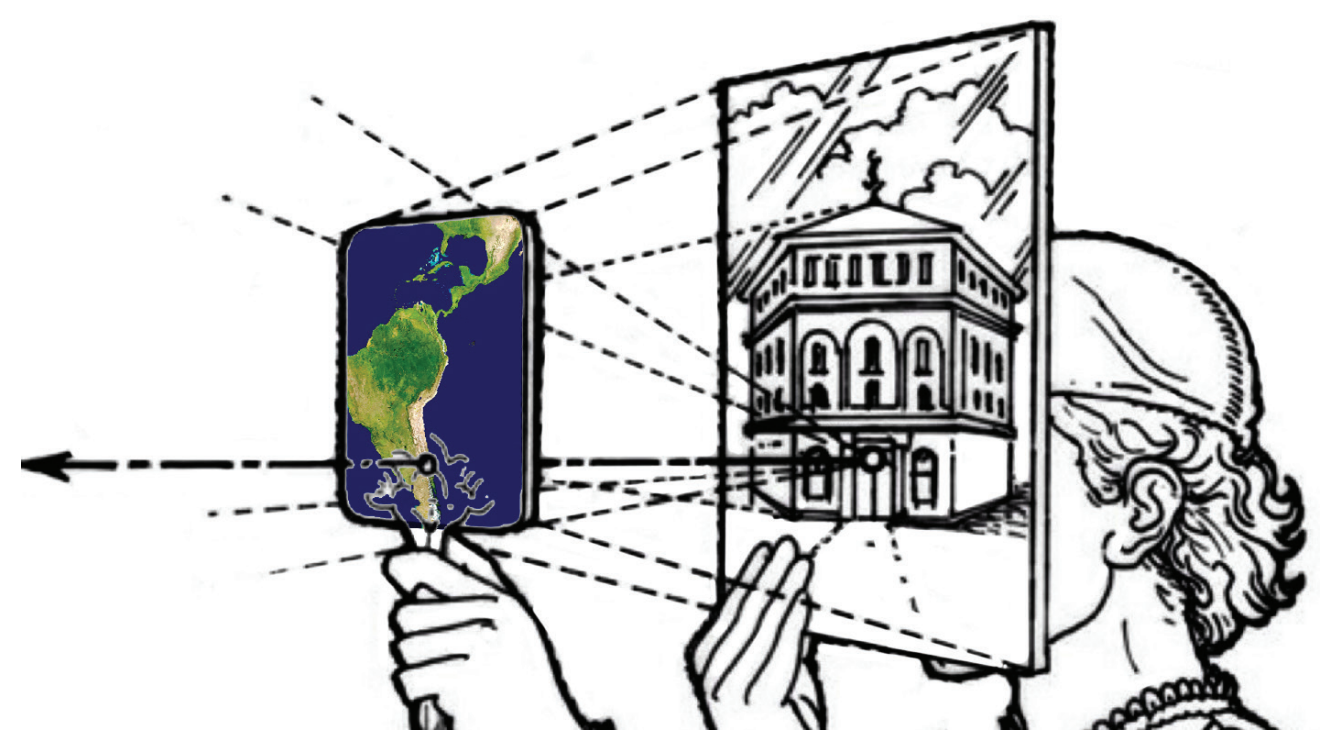

Figure 1. American Mirror. 
De Re Aedificatoria (printed in 1485) to Donato Bramante's plans for the Tempietto (1502) and Saint Peter in Rome (1506), to Michelangelo's dome at Saint Peter's (1546) to Andrea Palladio (1550-80). All scholarship credits this moment as the point of rupture between architecture and construction, between practical knowledge and abstract design. Banister Fletchers' book from 1896 already discussed the idea of late Renaissance as a break from tradition, a concept that dominated every interpretation since. ${ }^{15}$ Lefraive and Tzonis discuss this moment as "a daringly innovative, systematic, and coherent set of practices and ideas which continue to shape architectural practices today." ${ }^{16}$ In the words of Joseph Rykwert introducing his translation of Alberti's De Re Aedificatoria, "the essential difference between Alberti and Vitruvius is therefore that the ancient writer tells you how the buildings that you may admire as you read him were built, while Alberti is prescribing how the buildings of the future are to be built." ${ }^{17}$ This difference is crucial for my argument that the Americas had a significant impact on the history of Western architecture as early as the sixteenth century. It was here that a whole "new world" was built as prescribed by Alberti, Andrea Palladio, and Sebastiano Serlio, sometimes before their European counterparts, and often at a much larger scale.

Only seven years separate the publication of $D e$ Re Aedificatoria and the arrival of Christopher Columbus in the Caribbean. The impact of such events was tremendous, albeit minimized by a Eurocentric narrative that insists on locating the encounter as a consequence of European modernization. To accept that the Renaissance had many parallel developments is crucial for overcoming the diffusionist Myth of the European Miracle, as Blaut defined in the second chapter of his book on The Colonizer's Model of the World.$^{18}$ Let us consider for a moment that perhaps the encounter was a cause and not a consequence of European modernization.

In 1958 Edmundo O'Gorman published La invención de América: Investigación acerca de la estructura histórica del Nuevo Mundo y del sentido de su devenir. ${ }^{19}$ In this book, O'Gorman uses cartographic information to demonstrate that it was the encounter with the Americas that triggered a revolution in Europe and not the other way around. The bulk of O'Gorman's argument is that America was invented as an otherness that allowed Europe to place itself as a center. The world for Europeans in the fifteenth century was formed of three landmasses - Europe, Africa, Asia surrounded by the Mare Oceanum. Analyzing the medieval idea of orbis terrarum (earth island) in opposition to orbis alterius (other possible islands inhabited by unkown creatures), O'Gorman argues that the possibility of other inhabitable lands was deemed unacceptable by Christianity for it implied that the Bible was wrong on several accounts. He reminds us that for about a decade after 1492, the European nobility and their scholars thought that Columbus had arrived in islands of the Far East, Chipango (Japan), or China. Only after Columbus' fourth voyage (1502-1504) and 
Amerigo Vespucci's voyage of 1501-02, was it established that they had reached not Asia but another landmass of which they had no previous knowledge.

The shock of such understanding triggered a whole epistemological revolution in Europe. It is as if we wake up tomorrow with news that NASA, ESA, or CNSA found life on another planet. We would be forced to rethink everything we believe about ourselves. Such was the impact of the encounter with the Americas in the European consciousness of the early sixteenth century. Simply put, if the Bible contained no mention of this other landmass, perhaps the Bible should not be taken literally. It is not hard to imagine the impact of this paradigmatic shift in the works of Erasmus, Descartes, and Martin Luther. In the words of O'Gorman:

from the moment that the orbis terrarum was conceived as embracing the whole globe, both land and sea, and no longer circumscribed only to the Island of the Earth, man opened for himself the road to the conquer of the universe. The universe no longer appears to him as a strange, alien, and forbidden reality belonging to God and made for His sake, but a vast inexhaustible quarry of cosmic matter out of which man may carve out his world, depending not on divine permission, but solely on his own initiative, daring, and technical ability. ${ }^{20}$

O'Gorman explains that the invention of America tears down the medieval notion of the orbis terrarum, the inhabitable world, as an insular entity closely bounded by a menacing ocean, and replaces it with an image of the world as a fully masterable terraqueous globe. Here I need to highlight the concept of masterable. As synthesized by Descartes in the separation between res cogitans (mind) from res extensa (everything else), the minds of European men were now "masters" of everything else that is not only land and resources but also all women and all non-European men. For Descartes, there is no soul or mind in nature, only in men, angels, and God. This synthesis made Descartes second only to Plato in the Western tradition. Influenced by ancient, medieval, and scholastic sources, Descartes managed to break away from those traditions, thus influencing other early modern thinkers to emulate the break. Interestingly enough, no one asked why he thought of breaking with previous traditions, assuming that such epistemological rupture was based on his genius or the zeitgeist of the early sixteenth century. ${ }^{21}$

What exactly was the zeitgeist of the early sixteenth century, if not the ripple effect of the occupation of the Americas since 1492? Moreover, the fact that Descartes studied Logica Mexicana, published by Antonio Rubio in 1603, during his studies at the Jesuit college of La Fleche is never more than a footnote in books about his work. Descartes is still celebrated as someone that achieved such a break by the power of his mind only. According to 
400 years of Cartesian followers, the fact that the world around him was changing fast, due to the encounter with a whole range of civilizations and their alternative logical systems, had nothing to do with it.

The remaking of the world, according to its own technical ability as proposed by O'Gorman, was triggered by the encounter with the Americas and implemented simultaneously on both sides of the Atlantic. However, chronological parallelism does not mean symmetry. It was in the Americas that the project of modernity encompassed the scale of a whole continent, from the first Spanish settlements of the last decade of the fifteenth century to the Jeffersonian grid of the early nineteenth century and the Argentine law of Avellaneda of 1876. Here space, both real and abstract, acquired a central position in the transformation that we call modernity. Roberto Fernandez elaborated in his El Laboratorio Americano (1998) that America was the place where Europe inaugurated modernity through a monstrous negation of specific histories so that only space now existed. ${ }^{22}$ Bringing our discipline into the core of the problem, Fernandez continues by stating:

The systematic but not total destruction of vernacular cultures in the Americas demanded an instantaneous architecture, cities multiplied by fiat (doquier in the original Spanish), not as a consequence of rural concentration as in Europe since the early Middle Ages, but as centers of control and management of productive hinterlands. ${ }^{23}$

Another fundamental concept to understand the role of the Americas in the development of European modernization and its architectural theories is the modernity/coloniality conundrum. Sociologist Anibal Quijano is credited with the concept when he moved away from the economic-centric Dependency Theory to propose a World-System that explains the intricate relationship of modernization and colonization. ${ }^{24} \mathrm{~A}$ few years later, Arturo Escobar published Encountering Development: The Making and Unmaking of the Third World (1994), in which he elaborates on the thesis that there is no modernization without colonization, both being sides of the same coin. In the words of Escobar,

...some of the key notions that make up the conceptual corpus of this research program are thus: the modern colonial world system as the ensemble of processes and social formations that encompass modern colonialism and colonial modernities; although it is structurally heterogeneous, it articulates the main forms of power into a system. ${ }^{25}$

Walter Mignolo goes further by demonstrating that "the emergence of the Atlantic circuit during the sixteenth century made coloniality constitutive of modernity." ${ }^{26}$ I shall return to this articulation of modern/colonial as defined by Quijano, Escobar, and Mignolo in order to explore the spatial consequence of such processes. 


\section{THE GRID TESTED IN THE AMERICAS}

In the classic paper on "The Grid" by Barry Maitland (1979), ${ }^{27}$ we read that "the grid is anything which exists less for itself than as a discipline or frame of reference for something else. In its usual sense the word "grid" suggests something of a geometric nature (...) to select, relate, fix, or otherwise order a set of particulars or possibilities. Richard Sennett, in The Conscience of the Eye (1991) discusses how "the grid subdues those that must live there, disorienting their ability to evaluate relationships. The planning of neutral space is an act of dominating and subduing others." ${ }^{28}$ However, when discussing the history of the grid, Sennett jumped from the Roman Empire to the seventeenth century, deliberately ignoring the hegemony of the grid in the process of occupation of the Americas in the sixteenth century. In Gridded Worlds: an Urban Anthology (2018), editors Reuben RoseRedwood and Liora Bigon set out to:

...examine the relationship between the grid plan and political ideology; its role as a political technology of imperialism, colonialism, and the formation of the modern territorial state; and the various ways in which the production of "gridded worlds" has shaped the spatial imaginaries and everyday lives of urban inhabitants around the world. ${ }^{29}$

In order to do that they assembled a collection of articles that deconstruct, once and for all, the old diffusionist theory that the idea of the "grid" has a single origin. For the main argument of this paper referring to the "grid" in the Americas, I will return later to the chapters by Jill Grant and Setha Low. For now, allow me to reproduce the words of editors Rose-Redwood and Bigon when they assert that "if we are to move beyond Eurocentriccolonialist narratives of the grid, we need to develop more sophisticated theories and methods for analyzing the entangled histories of indigenous, colonial, and postcolonial gridded spaces in both the Global North and Global South," ${ }^{30}$ which is precisely my goal in this article.

Let us examine, for example, a small book published in the Dominican Republic in 1998. ${ }^{31}$ Based on a seminar held in Caracas three decades before, scholars Gabriel Guardia, Leonardo Benevolo, Paolo Portoghesi, Erwin Walter Palm, and Graziano Gasparini discussed the legacy of the colonial cities of the Americas. Arguing for the centrality of the Spanish experience, Guardia argues that we cannot call the American cities "daughters of the Renaissance," nor can we attribute them to Italian treatises since the Renaissance ideal cities were circular or radiocentric poligons, not abstract orthogonal grids prone to expansion. ${ }^{32}$ Besides, the gridded city is not at all a Renaissance invention despite its roots in Roman military strategy. Fray Francesc Eiximeniç had published his Quinna forma deu haber Ciutat bella e be edificada in 1386 and Villareal, a few miles north of Valencia, was founded in 1274 on a rectangular city with 
orthogonal streets. Guardia also reminds us that gridded cities existed in Mexico before the arrival of Europeans, Tenochtitlan and Cholula, for example, had orthogonal plans from around the time of Eiximeniç as did Teotihuacan a thousand years before that.

Guardia, therefore, prepared the terrain for the coup de grâce by Leonardo Benevolo. The Italian scholar started by arguing that the Renaissance changed architecture but did not change urbanism. "The examples cited in history books - Pienza, Urbino, Ferrara, Mantova, August, Anversa, Lisbon, Rouen, Vitry, Nancy and Palmanova are in some degree exceptions, built by unique circumstances that do not conform a general rule." ${ }^{33}$ The Renaissance, continued Benevolo, did not create a new city typology, it just intervened in existing medieval cities.

Benevolo was in full agreement with Lewis Mumford and his concept of medieval organic planning. According to Mumford, there is no Renaissance city. European urban concepts evolved from Medieval time to Baroque. Mumford wrote that "practically all of the 'renascence' building took place on medieval street plans, within the walls of essentially medieval cities, erected by crafts and guild still organized on medieval lines." 34

The colonial territory was where the Europeans could operate to create the largest number and, in certain aspects, the most relevant works of the sixteenth century. Moving closer to my argument that modernity has had a significant American component since the sixteenth century, Benevolo wrote that "the grid adopted in America comes from an operative tradition but also from a European cultural ideal applied only partially in the old continent but is present in everything considered modern. It is indeed an index of modernism." ${ }^{35}$ More recently, Clare Cardinal-Pett wrote that "the idea that the Mesoamerican city itself could have provided some precendent for Spanish colonial city planning gains much traction with the fact that many of the first "new" towns were in fact built on top of existing indigenous urban places. ${ }^{36}$ Setha Low's research on the pre-Colombian roots of the Hispanic plazas is by now quite well known, ${ }^{37}$ as well as Jesús Escobar detailed account of Mexico's Zocalo as an urban model for Plaza Mayor in Madrid. ${ }^{38}$

Could we say then that modernity started in the Americas? Benevolo did not pose such a question but ended his essay by stating that

...the urban design developed in the Americas in the sixteenth century, consolidated by the law of 1573 (Law of the Indies), is the only model of new cities produced by the Renaissance. This model continues to work for four centuries after being generalized by the neo-classical culture and served as a basis for the most impressive territorial transformation of the modern era: the colonization and urbanization of the United States. ${ }^{39}$ 
Back to the words that Fernandez uses to explain the Americas, "no territory as close to a pure modernity, from the Renaissance utopias to the energic application of the ideas of counterreformation (1600s), illuminist (1700s) and positivism (1800s)." ${ }^{40}$ Mumford understood very well the relationship between modernity and abstract territorial control (Fig. 2). In his words,

...capitalism became militaristic [in the sixteenth century] and a change in the entire conceptual framework took place with its abstract love of money and power. And first; new conception of space. It was one of the great triumphs of the baroque mind to organize space, make it continuous, reduce it to measure and order, and to extend the limits of magnitude, embracing the extremely distant and the extremely minute; finally, to associate space with motion and time. Those changes were first formulated by the painters and architects, beginning with Alberti, Brunelleschi, Uccello, and Serlio. ${ }^{41}$

Such power of abstraction is clearly visible in the Mexican cartography of the sixteenth century. In 1578 King Felipe II sent a questionnaire to all Spanish towns in the Americas, a kind of census aimed at organizing all this information on the other side of the Atlantic. The so-called Relaciones Geográficas is a priceless picture of the first decades of European occupation, and many of the reports include maps. Such maps display a variety of conceptions of space, from the early relational depictions of the

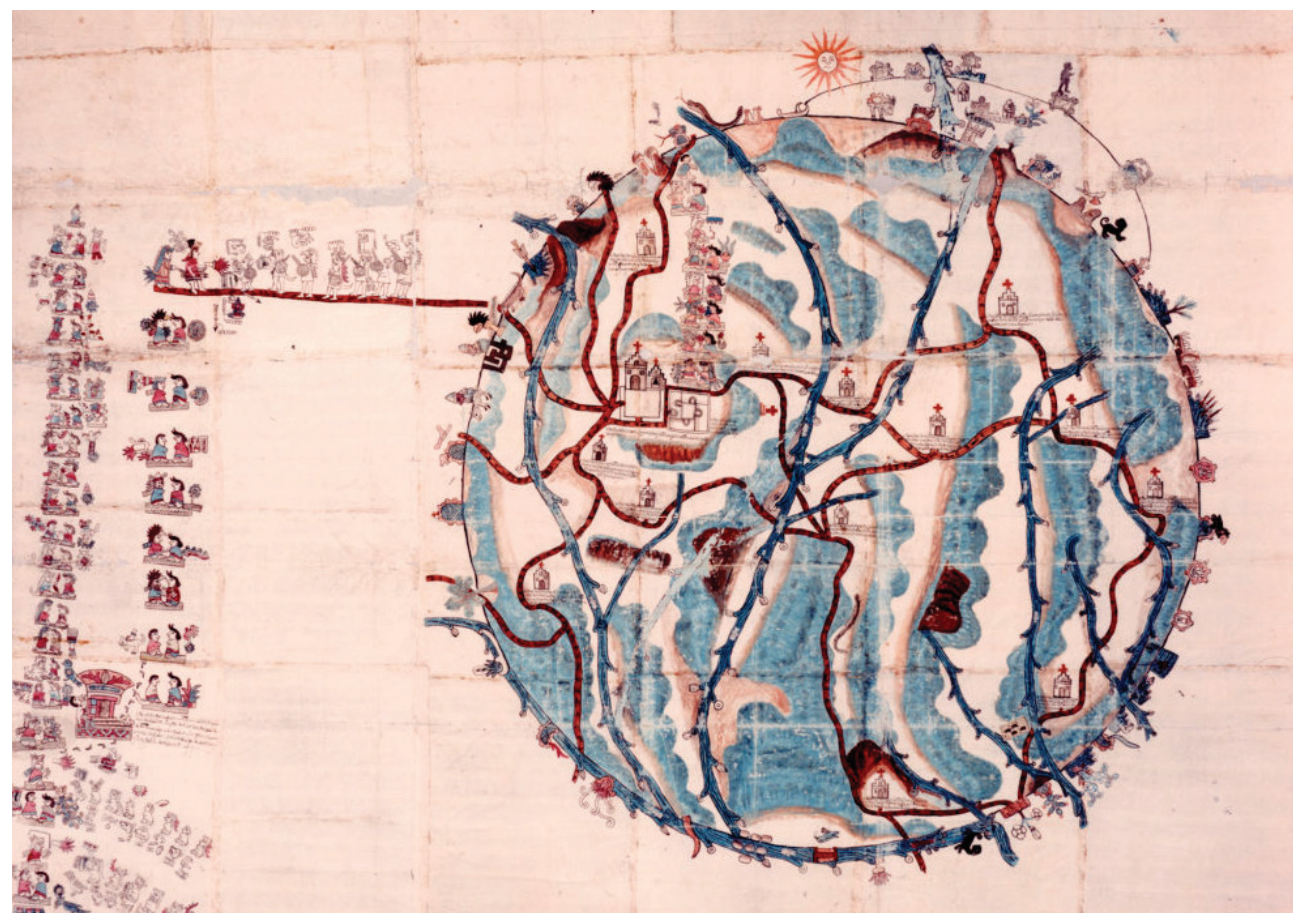

Figure 2. Map of Teozacoalco, Oaxaca, 1580. 
local Nahuatl and Mexica to the gradual introduction of abstract lines which were instrumental in assuring Spanish control. In the map of Teozacoalco, we read the relational perception of space with its geographic accidents connected to local rulers. Here the new churches built by the Spanish are already visible but are engulfed by a circular view of the world punctuated by the sacred mountains of the Nahua.

In the map of Ixcatlan, the territory is already organized in a European (birds-eye) perspective, and the sacred Nahua mountains are all matched by a chapel or church (Fig. 3). The pairing of mountains/sacred beings to churches/sacred beings was one of the most effective tools of colonization in the sixteenth- and seventeenth-century Americas. Our great cities to this day are called São Paulo, Asuncion, Rosário, Santiago, Santo Domingo, San Antonio, San Francisco, and Los Angeles. In the map of Zempoala, we see the abstract lines imposed over the territory and the geographical features reduced to markers in an overextended and overpowering grid.

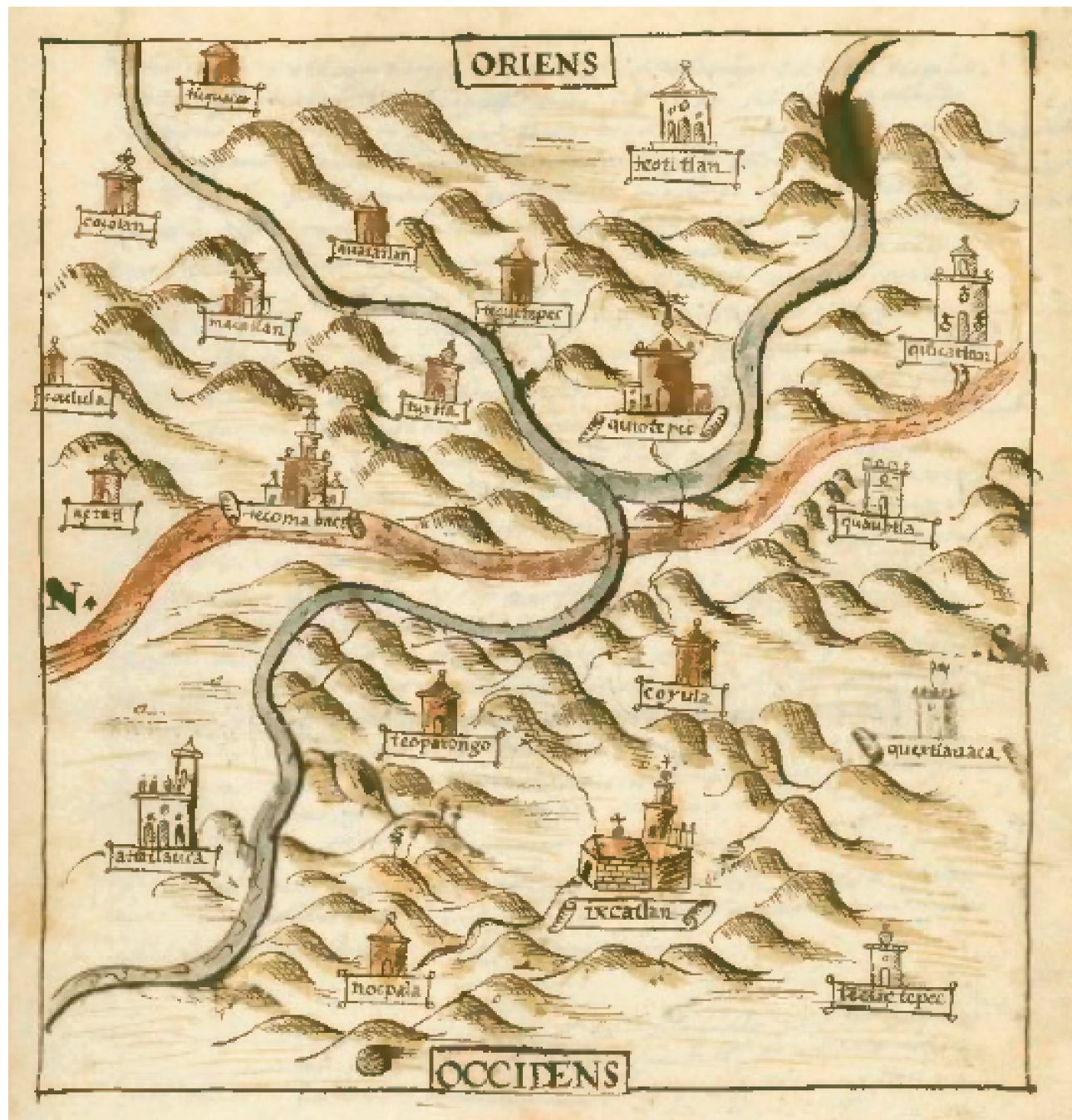

Figure 3. Map of Ixcatlan, Oaxaca, 1579. 
In Spacious World, Cartography, Literature, and Empire in Early Modern Spain (2004), Ricardo Padron shows that before the sixteenth century, a map was basically an itinerary with men located at the ground and traveling along the landscape. After Columbus, Vespucci, and Descartes, a map became an abstract tool of territorial description with men removed from it. The transformation from a relational map that places mankind in the middle and in direct contact with the landscape to an abstract map that places [European] men above and removed from the earth is all but complete in the Zempoala map of 1580 (Fig. 4).

The grid that Sennett overlooked and Benevolo acknowledged as the main urban form of the Renaissance was a powerful tool of colonization and control. Moreover, the grid was already in the Americas when Spanish

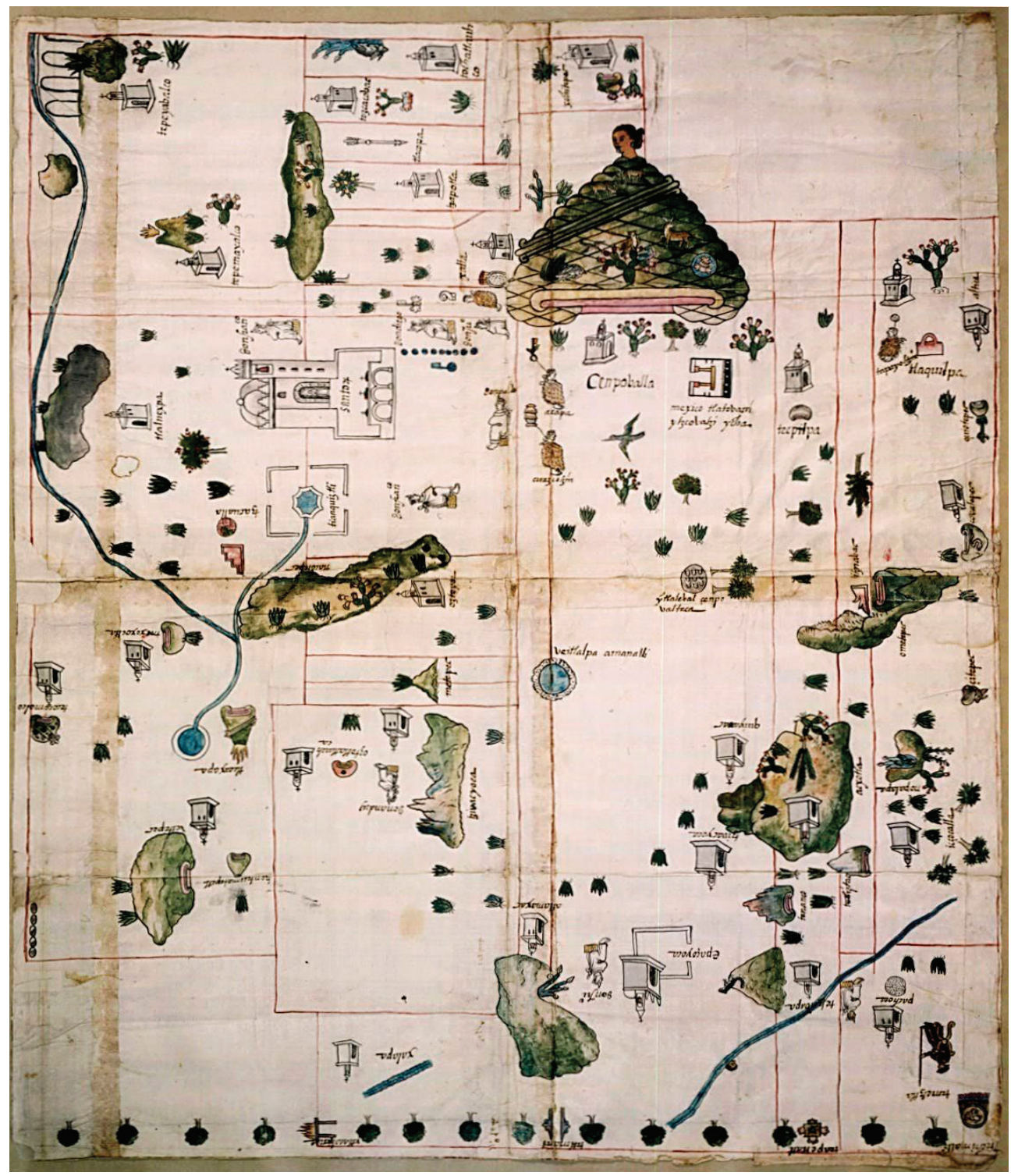

Figure 4. Map of Zempoala, Hidalgo, 1580. 
conquistadores arrived, and with the same meaning of celebrating a strong centralized authority. Graziano Gasparini has demonstrated that the preColombian plan of Cholula was the model for the 1531 plan of neighboring Puebla; their grids precisely aligned at 40 degrees NW-SE. ${ }^{42}$ Dora Crouch, Daniel Garr, and Alex Mundigo have also acknowledged that the "almost rectangular plan of Tenochtitlan agreed more with Renaissance ideals than [the Spanish] own experience in medieval Spain. Once they had the opportunity of living in a regularized city, they went on to establish this as the norm for colonial settlements." 43 The question of why it was established as the norm is discussed in Jill Grant's extensively scholarship on the flexibility of the grid to serve different political ideologies, from decentralized democracies to authoritarian empires, but settled lately on the idea that "the grid clearly signifies that planners were at work. It denies spontaneity and indigenous urban or landscape traditions. It imposes a rational conceptual order that transcends time, and proclaims the control and power of central authorities to shape space." 44

Architecture was, and still is, an important component of such control strategies. One question then remains unstudied: what was the impact of the encounter and the consequent rise in abstract thought on the architectural theories after 1492 ?

\section{THE IMPACT OF THE AMERICAS' LABORATORY ON EUROPEAN ARCHITECTURE}

Katheleen James-Chakraborty reminds us that Brunelleschi's convincing depiction of depth was accompanied by an increasingly sophisticated ability to frame and describe space, one probably informed by Florence's skilled merchants who learned to judge quantities visually. ${ }^{45}$ This happened a few decades before Columbus set foot in the Americas, but it needs to be understood as a piece of a much broader puzzle. The Portuguese started sailing in the mighty mare oceanum in the fourteenth century and in the second half of the fifteenth century the merchants that James-Chakraborty alludes to were not only Genoa and Venice but also from Seville, Lisbon, and Constantinople, soon to be renamed Istanbul. After Lorenzo de Medici's death in 1492 (what a year!), Florence had a decade of turbulence with the rise of Girolamo Savonarola, a theocratic leader that burned as many paintings and books as he could, from 1494 to 1498 . The middle ages were still around the corner, and Florence would only flourish again when two Medicis were elected popes: Leo X (1513-1521) and Clemente VII (1523-1534). Together they commissioned Michelangelo and Raphael to produce their best works.

The encounter with the Americas enormously impacted their papacies. In their time, Charles V of Spain was crowned Holy Roman Emperor and imposed Pope Adrian VI (elected in 1522, died the following year). In their time, Martin Luther declared the protestant reformation. And Clemente VII himself approved Copernicus' theory of heliocentrism. However, none of this registers in the history of architecture as consequences of the 
encounter/invention with the Americas; not even a footnote is spent on the issue. Pevsner wrote about secular architecture becomes progressively more abundant after the sixteenth century but never asked why religious architecture was losing space or what was behind the rise of secular thought. Because of the centrality of European history in the modern era, it is as if all those ideas just happened there by fiat.

Mignolo and Dussel wrote extensive literature discussing how Europe invented herself and the role of the Americas in this process. Pushing Edward Said's concept westbound, Orientalism can be seen as a precursor to the understanding that the "West" is an ideological construction that operates by selecting few and far between ancient sources to draft a coherent narrative that upholds European centrality. The argument for a more complex and often contradictory narrative is summarized in the diagrams below, published by Dussel, Krauer, and Tuma. ${ }^{46}$ (Fig. 5.) In the words of Dussel this was an

...ideological invention that first kidnapped Greek culture as exclusively western and European and then posited both the Greek and Roman cultures as the center of world history. This perspective can be considered erroneous from two standpoints. First, as we shall see, there was not yet a world history in an empirical sense. There were only isolated, local histories of communities that extended over large geographical areas: the Romans, the
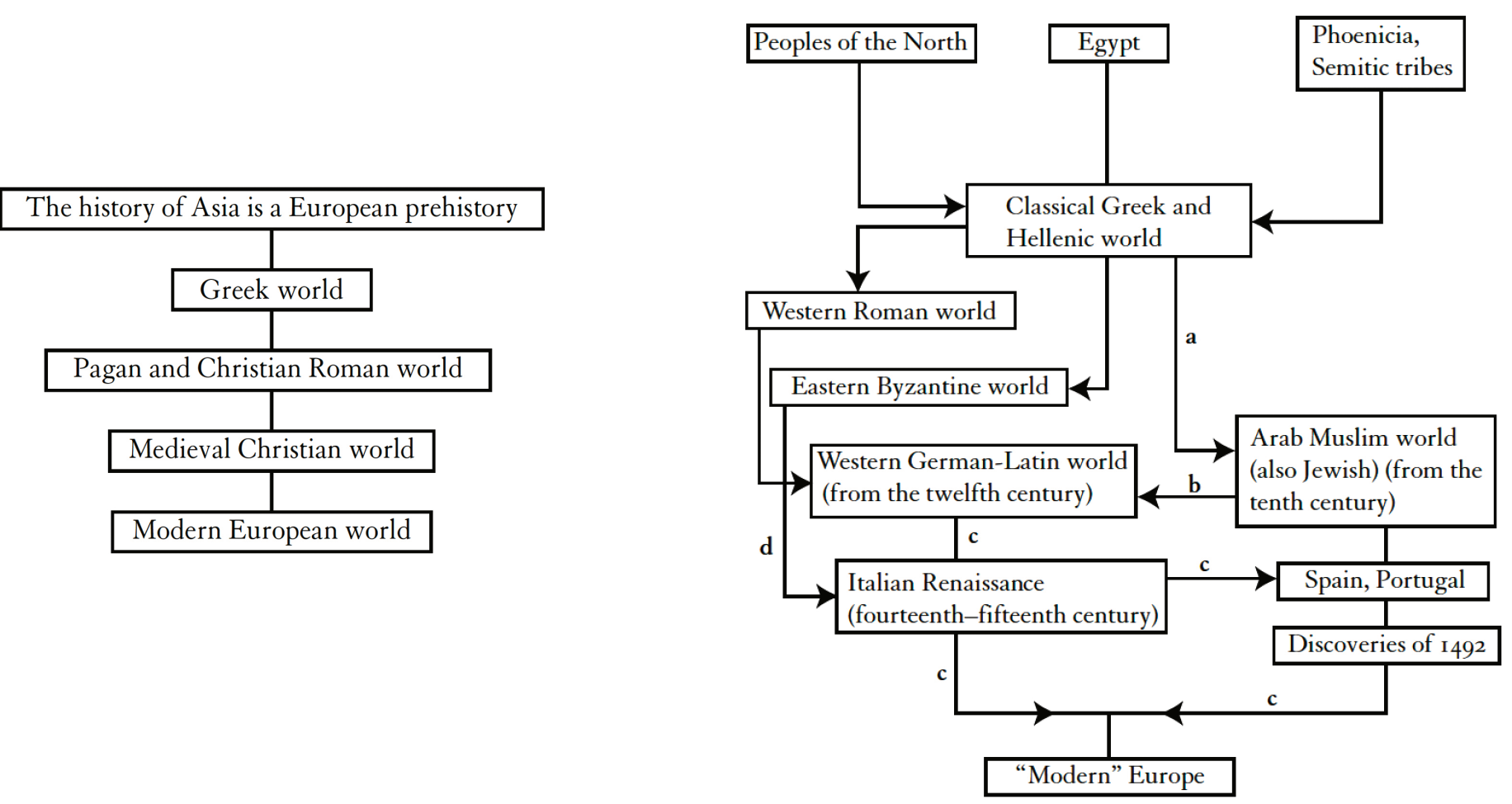

Figure 5. Diagrams of Western Culture from Dussel et al., 2000. 
Persians, the Hindu kingdoms, the Siamese, the Chinese, or the Mesoamerican and Inca worlds in America. Second, their geopolitical locations did not allow them to be a center. The Red Sea or Antioch, the final destination of commerce with the East, was not the center but the westernmost border of the Euro-Afro-Asian market. ${ }^{47}$

It is not hard to apply the same diagrams to the history of architecture to understand that we need a much more complex theory, much beyond the romantic reductionism of Greece-Rome-Gothic-Renaissance.

The reality is much more complex than the Western historiography of art and architecture wanted us to believe. It was in the Americas that ideas of abstract space were tested, and this was undoubtedly one of the triggers of modernity, not a consequence of it.

Back to Pevsner, his discussion of sixteenth-century Italian architecture was based on the idea that mannerism is unbalanced, discordant, the result of a self-consciousness that was a new experience to the West. ${ }^{48}$ What could have induced more self-consciousness and affected the balance of European knowledge more than the realization that thousands of years of geography scholarship and 1500 years of Christianity failed to anticipate the intellectual tectonic shift of 1492-1504?

Writing in 1983 (decades before most books by Dussel, Mignolo, and Escobar but decades after O'Gorman), Alberto Perez-Gomes locates a sense of crisis in the architecture of the sixteenth and seventeenth centuries as it abandoned any trace of higher meaning to become increasingly abstract and operational. According to Perez-Gomez, architecture was following Descartes, Galileo, and Newton with the rise of algebraization, functionalization, and technological rules. In Galileo, geometry and number were able to become instruments for the technical control of practical operations and, eventually, for an effective technological domination of the world. ${ }^{49}$ In Sir Isaac Newton's philosophy absolute time and space were not merely mathematical entities implicit in the experimental method, they were transcendental manifestations of God's omnipresence. ${ }^{50}$

On page 166 of Architecture and the Crisis of Modern Science, PerezGomez uses words very similar to O'Gorman when he argues that medieval Christianity had heavens as prototype of truth and when the new science reject the superiority of heavens the Earth became the field of exact science. As O'Gorman discussed seven decades ago, it was the encounter/ invention of the Americas that triggered the idea of a planet at the disposal of humankind. Before that, it was "sacrilegious to imagine that the world could be improved by human actions." 51

For this to happen, space had to be dissociated from the bodies that occupy it, and it is not a surprise that seventeenth- and eighteenth- 
century philosophers, from Descartes to Leibniz, assumed that places are only momentary subdivisions of universal and homogeneous space. ${ }^{52}$ Such separation of mind and body that was synthesized by Descartes was fundamental to the development of architectural drawing in general and perspective in particular. Perez-Gomes reminds us that perspectiva artificialis became popular with artists only when man began to view himself as subject and external reality. ${ }^{53}$ Not only was the mind/body divide influenced by the invention of the Americas, but the very act of occupying and controlling that much space was also an architectural problem.

One way in which our scholarship avoided the issue of architecture as tools of the modernity/coloniality process was by separating "architecture" treatises from "military ones." For the implementation of the modernity/ coloniality process and for the control of the American territories, they are one and the same. The plates that elaborated on how cathedrals and palaces should be built are inseparable from the plates that elaborated on how fortifications should be built. Our scholarship tends to relegate military treatises to footnotes, a strategy that helps differentiate us from our civil engineer competitors and to avoid the issues of power and control that have always been a feature of architecture. Back in the sixteenth and seventeenth centuries, such divisions did not exist and any experienced architect would have read military texts such as Alberti's Ludi mathematici (1452), Girolamo Cattaneo's Dell'arte militare (1584), Felipe II's Law of the Indies (1572), Simon Stevin's Oeuvres mathématiques (1634), and Samuel Marolois' Geometrie necessaire a la fortification (1628).

Meanwhile, in the Americas, abstraction was being effectively used to control the territory. Lines were imposed upon sites that had very different histories, and as a result, the colonial/modern project broke previous territorial organization and imposed a new order by symbolism.

\section{ABSTRACT SPACE AS AMERICAS' GREAT CONTRIBUTION TO THE "WEST"}

From recent scholarship stitching together Descartes, Gottfried Leibniz, and Isaac Newton, ${ }^{54}$ we learn that the rise of abstraction is an index of the modernity/coloniality project, which prompts the question of how the Americas participated in the development of abstract space? Ricardo Padron tells us that the new conception of abstract space "rationalized the known world according to the principals of Euclidean geometry. In this way it spoke of a new order of things, one in which mathematical abstraction promised to make the world apprehensible in ways that it had never been before. This novel, intellectual apprehensibility, in turn, supported an emerging culture of commercial, military, and political expansion." ${ }^{55}$ It supported modernity. Or, as reminded by Arturo Escobar, it supported both modernity and coloniality, two faces of the same coin.

Dussel uses the differentiation between first modernity (the Iberian Atlantic 
world of the sixteenth century) and second modernity (the Northern European protestant world of the eighteenth century) to elaborate on the rise of abstraction, which he locates in the sixteenth century. ${ }^{56}$ When we read Jürgen Habermas as the primary reference of modernity, we need to acknowledge that we are reading an analysis of the second modernity only. To really understand the transformations in architectural practices in Western civilization, we need to bring the first modernity (and its inseparable coloniality) into the picture.

In parallel to Dussel, Escobar defends that a full understanding of modernity implies:

1) locate its origins with the Conquest of America rather than the Enlightenment or the eighteenth century; 2) persistent attention to colonialism and inherent to capitalism; 3 ) the adoption of a world perspective in the explanation of modernity; 4) the understanding that modernity implies the subalternization of any non-European knowledge; and 5) to understand abstract universality and its role in the concrete world hegemony of Europe. ${ }^{57}$

Architecture has played a central role in this construction, and we have only started to properly study it with the lenses of modernity/coloniality.

\section{Notes}

1. Spiro Kostof, A History of Architecture: Settings and Rituals (New York: Oxford University Press, 1985), 433.

2. New publications dealing with the impact of the American occupation on Renaissance Europe include Kathleen James-Chakraborty, Architecture since 1400 (Minneapolis MN, USA: University of Minnesota Press, 2014); Clare Cardinal-Pett, A History of Architecture and Urbanism in the Americas (New York: Routledge, 2015); Fernando Luiz Lara, "Urbis Americana: Thoughts on Our Shared (and Exclusionary) Traditions," preface to Urban Latin America: Images, Words, Flows, and the Built Environment, ed. Bianca Freire-Medeiros and Julia O'Donnell (New York: Routledge, 2018); "Towards a Theory of Space for the Americas," FOLIO - Journal of African Architecture 2 (2020): 232-41.

3. Nikolaus Pevsner, An Outline of European Architecture (London: Penguin Books, 1964), 203.

4. Ibid., 209.

5. It is very interesting to compare twentieth century scholarship on the Tempietto, such as Earl Rosenthal, "The Antecedents of Bramante's Tempietto," Journal of the Society of Architectural Historians 23, no. 2 (1964): 55-74 - which barely mention the Spanish patrons and look only into Italian history to explain the building's novelty - with recent books such as Jack Freiberg, Bramante's Tempietto, the Roman Renaissance, and the Spanish Crown (Cambridge, UK: Cambridge University Press, 2014), in which the role of the Spanish monarchs and their goals are discussed as fundamental components of Bramante's more abstract design.

6. Liane Lefaivre and Alexander Tzonis, The Emergence of Modern Architecture: $A$ Documentary History from 1000 to 1810 (London: Routledge, 2004).

7. Charles C. Mann, 1493: Uncovering the New World Columbus Created (New York: Vintage, 2012).

8. Lefaivre and Tzonis, The Emergence, 17.

9. I am referring here to the works of Frantz Fanon, The Wretched of the Earth (New York:

Grove 1961); Edward Said, Orientalism (Harmondsworth, UK: Penguin, 1978); Enrique 
Dussel, La pedagógica latinoamericana (Bogotá: Nueva América, 1980); Homi K. Bhabha, "What Does the Black Man Want?," New Formations 1 (1987): 118-24; and Arturo Escobar, Encountering Development: The Making and Unmaking of the Third World (Princeton NJ, USA: Princeton University Press, 1994).

10. James M. Blaut, The Colonizer's Model of the World: Geographic Diffusionism and Eurocentric History (New York: Guilford Press, 1993), 7.

11. Alberto Perez-Gomez, Architecture and the Crisis of Modern Science (Cambridge MA, USA: The MIT Press, 1983).

12. Perez-Gomez certainly knew about the works of historian Edmundo O'Gorman, not only because he was the brother of architect Juan O'Gorman, but because of his thesis on the "invention of America" and its impact on European development, published in 1958.

13. Kostof, A History of Architecture, 433.

14. Arturo Escobar, "Worlds and Knowledges Otherwise: The Latin American Modernity/ Coloniality Research Program," Cultural Studies 21, nos. 2-3 (2007): 179-210; Walter Mignolo, The Darker Side of Western Modernity: Global Futures, Decolonial Options (Durham NC, USA: Duke University Press, 2011); David A. Brading, Orbe indiano: de la monarquía católica a la república criolla, 1492-1867 (Mexico City: Fondo de Cultura Económica, 2003); and Ricardo Padron, The Spacious Word: Cartography, Literature, and Empire in Early Modern Spain (Chicago: University of Chicago Press, 2004).

15. Banister F. Fletcher, A History of Architecture on the Comparative Method (London: B.T. Batsford, 1896), 439.

16. Lefaivre and Tzonis, The Emergence, 53.

17. Joseph Rykwert, Robert Tavernor, and Neil Leach, eds., Leon Batista Alberti: On the Art of Building in Ten Books (Cambridge MA, USA: The MIT Press, 1988), x.

18. Blaut, "The Myth of the European Miracle," in The Colonizers' Model.

19. Edmundo O'Gorman, La invencion de America: Investigacion acerca de la estructura historica del Nuevo Mundo y del sentido de su devenir (México City: UNAM 1958).

20. Ibid., 129.

21. Ramón Grosfoguel, "The Structure of Knowledge in Westernized Universities: Epistemic Racism/Sexism and the Four Genocides/Epistemicides of the Long $16^{\text {th }}$ Century," Human Architecture: Journal of the Sociology of Self-Knowledge 11, no. 1 (Fall 2013): 73-79.

22. Roberto Fernandez, El laboratorio americano. Arquitectura, Geocultura y Regionalismo (Madrid: Biblioteca Nueva, 1997), 11.

23. Ibid., 20.

24. Aníbal Quijano, "The Paradoxes of Modernity," International Journal of Politics, Culture, and Society 3, no. 2. (Winter 1989).

25. Escobar, "Worlds and Knowledges Otherwise," 190.

26. Mignolo, "The Geopolitics of Knowledge and the Colonial Difference," South Atlantic Quarterly 101, no. 1 (2002): 60.

27. Barry Maitland, "The Grid," Oppositions 15/16 (1979).

28. Richard Sennett, The Conscience of the Eye: The Design and Social Life of Cities (New York: Knopf /Random House, 1990), 60.

29. Reuben Rose-Redwood and Liora Bigon, eds., Gridded Worlds: An Urban Anthology (Cham, Switz.: Springer, 2018), 1.

30. Ibid., 16.

31. Miguel D. Mena, ed., La Ciudad Colonial del Nuevo Mundo: formas y sentidos (Santo Domingo: Jardin de las Delicias, 1998).

32. Gabriel Guarda, "Santo Tomas de Aquino y las fuentes del urbanismo indiano," in Mena, ed., La Ciudad Colonial, 26.

33. Leonardo Benevolo, "Las nuevas ciudades fundadas en el Siglo XVI en America Latina. Una experiencia decisiva para la historia de la cultura arquitetonica de 'Cinquecento'," in Mena, ed., La Ciudad Colonial, 81.

34. Lewis Mumford, The Culture of Cities (New York: Harcourt Brace and Co., 1938), 303.

35. Benevolo, "Las nuevas ciudades," 86.

36. Cardinal-Pett, A History of Architecture and Urbanism, 146.

37. Setha Low, "Indigenous Architecture and the Spanish American Plaza in Mesoamerica and the Caribbean," in Rose-Redwood and Bigon, eds., Gridded Worlds, 155-75.

38. Jesús Escobar, The Plaza Mayor and the Shaping of Baroque Madrid (Cambridge UK: Cambridge University Press, 2003), 195.

39. Benevolo, "Las nuevas ciudades," 93. 
40. Roberto Fernandez, El laboratorio americano, 16.

41. Mumford, The Culture of Cities, 364.

42. Graziano Gasparini, "The Pre-Hispanic Grid System: The Urban Shape of Conquest

and Territorial Organization," in Settlements in the Americas, ed. Ralph Bennett (Newark NJ, USA: University of Delaware Press, 1993), 89.

43. Dora Couch, Daniel Garr, and Alex Mundigo, Spanish City Planning in North America (Cambridge MA, USA: The MIT Press, 1982), 37.

44. Jill Grant, "The Dark Side of the Grid Revisited: Power and Urban Design," in Rose-

Redwood and Bigon, eds., Gridded Worlds, 96.

45. James-Chakraborty, Architecture since 1400, 36.

46. Enrique Dussel, Javier Krauel, and Virginia C. Tuma, "Europe, Modernity, and

Eurocentrism," Nepantla: Views from South 3, no. 1 (2000): 465-78.

47. Dussel et al., "Europe, Modernity, and Eurocentrism," 468.

48. Pevsner, An Outline, 209.

49. Perez-Gomez, Alberto. Architecture and the Crisis of Modern Science, 10.

50. Ibid., 78.

51. Ibid., 166.

52. Arturo Escobar, "Culture Sits in Places: Reflections on Globalism and Subaltern

Strategies of Localization," Political Geography 20 (2001): 143.

53. Perez-Gomes, Architecture and the Crisis, 174.

54. Walter Mignolo and Arturo Escobar, eds. Globalization and the Decolonial Option (London: Routledge, 2013); Jorge Cañizares-Esguerra, Nature, Empire, and Nation:

Explorations of the History of Science in the Iberian World (Redwood City CA, USA:

Stanford University Press, 2006); Grosfoguel, "The Structure of Knowledge," 73-79.

55. Padron, The Spacious Word, 32.

56. Dussel's argument is that "modernity, as a new paradigm of daily life and of historical, religious, and scientific understanding, emerged at the end of the fifteenth century in connection with control over the Atlantic (...) In other words, since Holland, France, and England developed the possibilities already opened up by Portugal and Spain, they constituted the second modernity." Dussel et al., "Europe, Modernity, and Eurocentrism," 472.

57. Escobar, Encountering Development, 38.

\section{Credits}

Figure 1: montage by the Author.

Figures 2-4: courtesy of $@$ the Nattie Lee Benson Library, University of Texas at Austin. Figure 5: image from Enrique Dussel, Javier Krauel, and Virginia C. Tuma. "Europe, Modernity, and Eurocentrism" Nepantla: views from South 1, no. 3 (2000).

Fernando Luiz Lara is a Professor and Director of the Graduate Program in Architectural History at the University of Texas at Austin, where he holds the Potter Rose Professorship in Urban Planning. His research interests deal with theorizing spaces of the Americas with emphasis on the dissemination of architecture and planning ideas beyond the traditional disciplinary boundaries. In his several articles Prof. Lara has discussed modern and contemporary architecture of the Americas, their meaning, context and social-economic insertion. His latest publications include Excepcionalidad del Modernismo Brasileño (2019); Modern Architecture in Latin America (2015, with Luis Carranza, Hamilton Award runner up 2015) and Quid Novi?: Architectural Education Dilemmas in the 21 $1^{\text {st }}$ Century (2015, with Sonia Marques eds., Anparq best book award 2016).

E-mail: fernandolara@utexas.edu 